\title{
TERORIZAM KAO OBLIK POLITIČKOG NASILJA
}

\author{
Svetislav Lutovac \\ Nezavisni univerzitet Banja Luka \\ Nikoleta Lutovac \\ Ministarstvo obrazovanja Republike Srbije
}

Sagledavajući period tokom poslednjih decenija prošlog veka može se

Sjednostavno uočiti da je do danas terorizam u svom veoma složenom izdanju doneo najdramatičnija iskustva posle Drugog svetskog rata.

$U$ poslednjim decenijama XX i početkom XXI veka terorizam, posebno međunarodni terorizam, postaje pretnja ne samo teritorijalnom integritetu suverenih naroda i država, već i miru, slobodi i razvoju celokupnog čovečanstva. Savremeni terorizam je u stalnoj ekspanziji koja se prvenstveno ispoljava u kvalitativnom domenu.

Zahvaljujući konstantama koje ga pokreću on se ciklično obnavlja, i to svaki put savršeniji i efikasniji sa dodatnim elementima iznenađenja.

Ključne reči: terorizam, međunarodni terorizam, ekspanzija, ciklično obnavljanje

\section{Uvod}

lako postoje mnogobrojne definicije terorizma Svet ne poznaje saglasnost tj. kon-

senzus u praktičnom valorizovanju ovih definicija iz prostog razloga za nekoga je to čin terora za druge to predstavlja legitiman čin odbrane, ono što nekom donosi slavu i naziv borca za slobodu, drugome donosi omraženost i naziv zlikovca i teroriste.

Ove razlike prvenstveno u tumačenju proizilaze iz društveno-političkih i religijsko-kulturoloških pristupa ovom problemu.

Možda bi se jedan pravi pristup o ovoj pojavi pravilno sagledao u rečima čoveka koji je i sam bio žrtva ove nemani i koji je položio život, pred istom (gosp. Ulof Palme) „Teror će uvek biti teror, zločin će uvek biti zločin čak i onda kada je izvršen u ime velikih principa i velikih ideala".

Terorizam je danas sve rasprostranjeniji, pojavljuje se u nekim novim oblicima, ciklično se obnavlja, sve je savršeniji i efikasniji sa velikim dodatnim elementima iznenađenja i gotovo da ne postoji nijedna zemlja u svetu koja nije njemu izložena ili joj ne preti opasnost od terorističkih akcija.

Teroristički napad na svetski poslovni centar u Njujorku i vojno strateške objekte (Pentagon) u Vašingtonu 11. septembra 2001. godine, sa najvećim brojem ljudskih žrtava u istoriji terorizma, cela planeta sa užasom i nemoćno posmatrala je kako gore zgrade u Njujorku, kako izbezumljeni roditelji iznose mrtvu decu i svoje najbliže na drugom delu zemaljske kugle 
(Beslanu) upozorio je na nove oblike, sredstva, metode i dalekosežnost posledica ovog savremenog zla a sa druge izazvao je i sveukupnu mobilizaciju antiterorističkih snaga u mnogim državama sveta. U procesu suprotstavljanja terorizmu uključuje se celokupna međunarodna zajednica a unutar svake države svi državni organi, snage odbrane, bezbednosti i zaštite.

Antiterorizam predstavlja primenu niza, preventivno-zaštitnih i bezbedonosnih-odbranbenih mera uključujući i aktivnosti obaveštajnih i kontraobaveštajnih službi radi otklanjanja ili smanjivanja opasnosti od terorizma uključujući uz ove subjekte pravosudne i bezbedonosne organe uz minimalno angažovanje vojnih snaga (uglavnom specijalnih jedinica).

Borba protiv terorizma postaje prioritet međunarodne zajednice.

Izdvajaju se ogromna novčana sredstva za osavremenjavanje i unapređivanje jedinica i službi za protivteroristička dejstva.

Skoro sve države u svojim krivičnim zakonodavstvima uvode novo krivično djelo „TERORIZAM“.

U našoj zemlji još u okviru bivše SRJ u članu 42 Ustava stoji: „Zabranjeno je delovanje političkih, sindikalnih i drugih organizacija koje je usmereno na nasilno rušenje ustavnog poretka narušavanje teritorijalne celokupnosti SRJ, kršenje garantovanih prava i sloboda čoveka i građanina ili izazivanje nacionalne, rasne i verske i druge netrpeljivosti ili mržnje. Zabranjeno je osnivanje tajnih organizacija i paravojski“.

Terorizam pored svojih klasičnih oblika kao što su atentati, paljevine, otmice brodova, napadi na policijske stanice, železničke stanice, pozorišta, sportske manifestacije i druge sve više se ispoljava u organizovanim oblicima koji su često povezani na međunarodnom planu i ostvarujući time političke i finansijske ciljeve otmicama diplomatskog osoblja, lica iz političkih, pravosudnih, privrednih, političkih i vojnih struktura kao i otmicama aviona, držanjem talaca.

Ono što možemo konstatovati da terorizam karakteriše jeste odlična organizovanost, obučenost i opremljenost, a kao efekat i ishod neverovatna brutalnost i nehumanost sa velikim brojem u načelu nevinih žrtava i velikom materijalnom štetom.

\section{Definisanje političkog nasilja}

Političko nasilje podrazumeva postojanje svesti o političkim ciljevima, organizovanost i posedovanje sredstava, kojima se politički ciljevi mogu postići.

Postojanje svesti o političkim ciljevima znači da postoji od strane pojedinca ili grupe usvojena politička filozofija i saznanje da postojeće društveno-političko stanje nije u skladu sa njom i da je treba nasilno rušiti.

U organizovanosti političkog nasilja zastupnici i predstavnici političkog nasilja, stvaraju organizacije, čiji članovi imaju zajednička opšta filozofska, ideološka, politička i religiozna mišljenja. Organizacije imaju osnovni cilj da nasilnim metodama i sredstvima ostvare ili zadrže političke pozicije u društvu i državi. One stvaraju svoju strategiju i taktiku kojom će ostvarivati ciljanu strategiju.

Nasilje u sferi politike pojavljuje se u legalnom i ilegalnom političkom polju.

Kroz istoriju ljudskoga roda politika i nasilje su tesno povezani a posebno to dolazi do izražaja sa uvođenjem hijerarhijske vlasti i nastankom država. Država je sebi obezbedila legalni monopol na oružano nasilje, tako što svako protivljenje vlasti i kršenje zakonskih normi od strane pojedinaca, grupa, organizacija sankcionisala je primenom nasilnih metoda. 
Isto tako država ima ulogu da održi postojeće stanje i društvene relacije dok se one zakonskim putem drugačije ne urede. U njenoj nadležnosti nalaze se mogućnosti da koristi sve institucije i organizacije kao što su vojska i policija da bi omogućila svoje neometano funkcionisanje.

Policija i vojska po nekim shvatanjima kao državne institucije sile imaju osnovnu ulogu u čuvanju funkcionisanja postojećih društvenih i državnih odnosa pa se zato smatraju konzervativnim društvenim institucijama, teško prilagodljivim novim trendovima kretanja i zahtevima za promenama.

Političko nasilje se može odrediti kao direktna ili indirektna primena sile u domenu politike i političkog, odnosno kao direktna ili indirektna upotreba sile nad svešću, nad telom, nad životom ili materijalnim dobrom stvarnog ili potencijalnog političkog protivnika.

Kao cilj nelegalnih političkih grupa i pojedinaca koristeći nezadovoljstvo lokalnog stanovništva u sprovođenju nasilnih političkih akcija kojima podrivaju postojeće političke vladajuće snage je da sruše vlast, zakonsko društveno uređenje, državne i parlamentarne institucije i uspostave svoju vlast i vladavinu svojih zakona ili da odvoje deo zemlje i stvore novu državu u kojoj će uspostaviti svoju vlast.

Obično protivnici političke vlasti i vladajuće politike kada pribegavaju nasilnim metodama borbe nalaze se u ilegalnoj sferi društvenog života.

Svesni da podležu sankcijama zvanične uspostavljene vlasti njihova sredstva su verbalna a često se organizuju u vidu ilegalnih oružanih grupa, pojedinaca i organizacija stvarajući mozaike ilegalnih institucija društvenog života, uspostavljaju kontakte i prihvatanje informativne, edukativne, finansijske, materijalne i oružane pomoći iz inostranstva.

Fizičko nasilje u politici ima opravdanja jedino u slučaju kad je odgovor na torturu vlasti i kada su isrcpljena sva sredstva mirnog traženja demokratizacije određenog društva.

\section{Vrste i oblici političkog nasilja}

Uočavajući mnogobrojne kriterijume klasifikovanja političkog nasilja postoji veliki broj tipologija.

Prema sadržaju moguće je odrediti dve vrste nasilja i to:

- psihičko i

- fizičko.

Po načinu vršenja:

- direktno i

- indirektno.

Po načinu vršenja tj. prema kvantitativnom obimu subjekta možemo razlikovati individualno od kolektivnog nasilja, po vremenu trajanja trenutno od dugotrajnog, po rasprostranjenosti delovanja na masovno i punktualno, pa zatim racionalno i iracionalno, zatim institucionalizovano i strukturalno i drugo nasilje. Po obliku u kojem se političko nasilje javlja deli se na osnovno i složeno.

U osnovne oblike spada: pritisak, prinuda, psihofizičko zlostavljanje, pretnja silom, političko ubistvo, atentat, diverzija i drugo. A u složene oblike političkog nasilja svrstavamo: nemire, nerede, nasilne proteste, pobune, subverzije, represije, ustanke, ratove, teror i terorizam.

Složeni oblici nasilja nisu samo prosti skup više osnovnih, već su često njihov međuzavistan i protivurečan $\mathrm{spoj}^{1}$.

\footnotetext{
${ }^{1}$ „Teorija politike-rider“ Dragan Simeunović, str. 153-155, Nauka i društvo, Beograd 2002. godine.
} 


\section{Osnovni oblici političkog nasilja}

Prinuda sama po sebi kao radnja podrazumeva nasilje kao direktnu ili indirektnu upotrebu sile.

Prinuda ima za cilj ostvarenje interesa, namera i volje subjekata koji prinuđuju.

Ovi interesi i namere su obično suprotni interesima i namerama a posebno gotovo uvek spremni volji onoga ko se prinuđuje. Uz pomoć stvarne ili nameravane upotrebe sile objekat nasilja se protiv svoje volje, prinuđuje na vršenje ili ne vršenje odgovarajuće radnje ili niza radnji. Te radnje u stvari vode realizaciji interesa i namera onoga koji vrši prinudu.

Za razliku od prinude koja podrazumeva upotrebu direktne ili indirektne sile pritisak se vrši bez direktne upotrebe sile. Osnovni cilj pritiska je realizacija određenih interesa kroz izazivanje straha od povreda fizičkog integriteta i narušavanja identiteta ukoliko se radi o pojedincu ili grupi ili narušavanju teritorijalnog integriteta ukoliko se radi o državi kao posledicama u slučaju neizlaženja u susret subjektu pretnje.

Pretnja silom se može ispoljiti u svom institucionalizovanom obliku te prema tome legalnom i legitimnom nasilju ali isto tako i u svom neformalnom i individualnom vidu odnosno kao nelegalno i nelegitimno nasilje.

U zavisnosti od intenziteta ostvarljivosti pretnje kao i ukupnih ugrožavajućih mogućnosti onoga koji preti, pretnja silom može predstavljati potencijalno ili stvarno nasilje. Što znači da nije svaka pretnja silom nasilje već samo ona koja jeste ili izgleda onome kome se preti ozbiljna i ostvariva.

lako ubistvo i atentat kao osnovni oblici političkog nasilja na prvi pogled deluju vrlo slično, dubljom analizom se uočavaju velike razlike između ova dva pojma.

Političko ubistvo predstavlja fizičku likvidaciju stvarnog ili potencijalnog protivnika i ono se vrši kao vid sankcija zbog nečijeg političkog ubeđenja ili delatnosti ali i kao preventivno delo. Za razliku od atentata koji može biti neuspeo, s' političkim ubistvom to ne može biti slučaj. Atentat je uglavnom usmeren na jednu ličnost ili na veoma mali broj osoba dok političko ubistvo može poprimiti masovan karakter. U istoriji ima mnogo masovnih političkih ubistava (Nacističko uništavanje Jevreja u Drugom svetskom ratu, Staljinove čistke za vreme vladavine posle Drugog svetskog rata i sl.).

Takođe još jedna bitna razlika predstavlja i to što pojam atentata podrazumeva postojanje zavere što ne mora da bude slučaj i kod političkog ubistva.

Pored logičkih razlika između ovih pojmova atentat i političko ubistvo se razlikuju i u načinu odnosno sredstvima izvršenja.

Uglavnom atentat se izvodi vatrenim oružjem, eksplozivnim sredstvima, a ređe hladnim oružjem. Dok za politička ubistva izbor sredstava je neograničen (od primene otrova kao u nacističkim logorima gasne komore) i mnoga druga.

Pored političkog ubistva postoji i političko samoubistvo.

Ono predstavlja vid političkog protesta i ovakvim samouništenjem se uglavnom želi ukazati na neke nepravedne odnose u društvu.

Diverzija u političkom smislu predstavlja odvraćanje pažnje protivnika ili zavaravanje traga i namere. Iz ovog akta se krije onaj pravi akt kome ovaj prvi služi kao kamuflaža².

\footnotetext{
${ }^{2}$ „Teorija politike-rider“ Dragan Simeunović, str. 153-155, Nauka i društvo, Beograd 2002. godine.
} 


\section{Složeni oblici političkog nasilja}

Otvorena ili tajna subverzija predstavlja direktnu ili indirektnu aktivnost organizovanu sa strane, koja je usmerena protiv postojećeg režima, pravnog, političkog i društvenog uređenja jedne države.

U političkom smislu ona kao sredstvo borbe predstavlja aktivnost koju u uslovima mira protiv jedne države ili organizacije preduzima druga država ili organizacija da bi izazvala prevrat ili smenu vlasti a sve to da bi na vlast dovela njoj odgovarajuće snage.

Termin „SUBVERZIJA“ je prvi put upotrebljen u preambuli Alijanse zaključene 20.11.1815. godine između Velike Britanije, Rusije, Austrije i Pruske.

U samom tekstu pomenute preambule svaki pokušaj ponovnog dovođenja na vlast Napoleona Bonaparte označen je kao akt „SUBVERTI“ odnosno kao akcija usmerena na preokret tj. usmerena protiv postojećih režima i društveno političkih uređenja zemalja potpisnica alijanse.

Subverzivne aktivnosti i njeni oblici mogu biti veoma različiti počevši od štampanja i rasturanja propagandnih letaka pa sve do ubacivanja u zemlju oružja i vojnog materijala za planirane oružane akcije subverzivnih terorističkih grupa ${ }^{3}$.

Politička pobuna određuje se kao vid lične, grupne ili kolektivne aktivnosti koja ima za cilj suprotstavljanje legalnom, ali isto tako i nelegalnom režimu.

Samim tim ovi ciljevi se prema proceni vođa pobune ne mogu ostvarivati mirnim putem već se njihova realizacija pospešuje kroz planirano i organizovano izvođenje nasilja.

Represalija je konkretna forma obične nelegalne represije od strane vlasti ili zavojevača na zauzetoj teritoriji nad stanovništvom u cilju odmazde ili zastrašivanja. Žrtve ovog nasilja nisu samo odrasli muškarci kao potencijalne individue ili grupe koje su sposobne da pruže otpor već i žene, deca i starci.

Kao poseban vid represalije je „retalijacija“ koja predstavlja uzvraćanje neke države, tj. međunarodnog subjekta istim načinom na neki čin povrede međunarodnog prava.

Savremeno međunarodno pravo zabranjuje sve represalije koje predstavljaju upotrebu sile i jedno od osnovnih načela pozitivnog međunarodnog prava (koje je uključeno i u povelju UN) zabranjuje upotrebu sile ili pretnju silom, pa samim tim i represalije te vrste.

Sami pojmovi teror i terorizam su veoma slični, međutim neophodno je ustanoviti njihovo razlikovanje.

Njihova sličnost se ogleda u tome što su oba „oružje manjine“ i što samim tim teže izazivanju straha ne kod žrtve već straha kod društvene grupe kojoj žrtva pripada.

Teror je oblik kontinuiranog sprovođenja nasilja koji ima za cilj održavanje na vlasti što bi se moglo definisati kao „NASILJE VLASTI“.

Za terorizam možemo reći da je nasuprot tome oblik nasilja uperen protiv nečije i nekakve vlasti.

Jedan od svakako najpoznatijih primera terora iz našeg okruženja je svakako bio teror Staljinovog režima u bivšem SSSR-u i ostalim socijalističkim zemljama.

Može se reći da je u ovom slučaju nasilje sprovođeno ne samo nad stvarnim nego i mogućim protivnicima sistema, pri čemu gotovo svako može biti sumnjiv.

Smatra se da je u tzv. Staljinovim čistkama nastradalo nebrojeno mnogo ljudi, a veoma veliki broj ljudi i neistomišljenika je svoj spas potražilo i našlo u emigracijama širom sveta ${ }^{4}$.

\footnotetext{
3 „Politička enciklopedija“ str. 1040, Savremena administracija, Beograd 1975. godine.
} 


\section{Definisanje terorizma}

U najranijoj istoriji ljudskog društva svakako je postojalo nasilje u svim svojim oblicima primereno stadijumu razvoja čovečanstva. Termini teror i terorizam se prvi put javljaju za vreme „JAKOBINSKE DIKTATURE“ u francuskoj revoluciji.

Reč Terorizam potiče od francuske reči TERREUR koja označava strah, užas. Terorizam u političkom smislu predstavlja akciju nasilja koja se primenjuje iz političkih razloga radi zastrašivanja i bespoštednog slamanja otpora onoga prema kome se vrši ${ }^{5}$.

Jedan od najranijih vidova i oblika terorizma bio je individualni terorizam koji je označavao primenu nasilja ili likvidaciju pojedinca od strane pojedinca, a kao primeri ovog vida terorizma u istoriji ima dosta još iz vremena antičkog doba gde se pribegavalo borbi protiv tirana i tiranije, po Ksenofontu ubice Tirana nisu kažnjavane već su slavljene, a u Rimu po Ciceronu su to smatrali za najsjajniji od svih podviga naročito ako je ubica Tirana bio blizak sa tiraninom.

Prateći ovu pojavu Terorizam je opstajao i sve svoje oblike prilagođavao aktuelnim potrebama i raznim političkim interesima tako da do sada ni jedan poznati društveno-politički sistem (bilo da se radi o demokratskom sistemu ili diktaturi) nije bio sam po sebi dovoljan da društvo zaštiti od terorizma.

Prisutna su razna mišljenja i definicije ali ni jedna definicija terorizma nije prihvaćena kao jedinstvena od strane svih država ili pak od strane određenih međunarodnih organizacija.

Jedan od glavnih razloga koji su doprineli neprihvatanju jedinstvene definicije terorizma od strane svih zemalja međunarodne zajednice upravo leži u činjenici da terorizam uvek sadrži političke pobude i motive.

Upravo zbog toga pojedine zemlje se podržavaju a druge kažnjavaju za iste kategorije terorizma. Takvo neprincipijalno ponašanje pojedinih država, a pod njihovim pritiskom i šire međunarodne zajednice, doprinosi neefikasnosti međunarodnih konvencija i akata donesenih radi suzbijanja terorizma.

Američki državni sekretar Kolin Pauel je aprila 2001. godine istakao da je „Terorizam poput zloćudne bolesti. Mnogi od vas su me čuli kako hvalim pozitivne aspekte globalizacije, ali terorizam predstavlja onu drugu stranu medalje time što koristi ublažavanje restrikcija u pogledu slobode kretanja, poboljšanja u domenu komunikacija i internacionalizaciju bankar-skog poslovanja, dakle sva ona dostignuća koja delovanje terorista u izvesnoj meri čine lakšim". ${ }^{6}$

Na spisku „STEJT DEPARTMENTA“ tačnije njegove kancelarije koordinatora za borbu protiv terorizma, koja pravi spisak terorističkih organizacija i zemalja koje podržavaju terorizam, a prihvata ga međunarodna zajednica, nema Čečena koji su samo separatisti što je poznat scenario i sa svim OVK-ima, ANA-ima i sličnim albanskim „pobunjeničkim gerilama“.

$\mathrm{Na}$ američki spisak pridodati su tzv. nova IRA i Kolumbijske ujedinjene snage za samoodbranu, dok su Japanska „crvena armija“ i Peruanski „TUPAK AMARU“ obrisani jer je procenjeno da više ne postoje.

\footnotetext{
${ }^{4}$ "Teorija politike-rider“ Dragan Simeunović, str.158, Nauka i društvo, Beograd 2002. godine.

5 „Politička enciklopedija“ str. 1079, Savremena administracija, Beograd 1975. godine.

${ }^{6}$ C. Powel, 30.April 2001.godine, povodom objavljivanja izveštaja Državnog sekretara o terorizmu u svetu u 2000. godini.
} 
Stavljanje na ovaj spisak povlači sledeće posledice:

Zabranjeno je pružanje finansijske ili bilo kakve druge materijalne pomoći sa ovoga spiska predstavnicima ili pojedincima članovima ovih organizacija, biće im uskraćena ulazna viza u SAD i mogu biti proterani iz zemlje.

Američke finansijske institucije obavezne su da imovinu ovih organizacija i njihovih agenata zamrznu, te da o tome obaveste ministarstvo finansija SAD.

U spisku koji sledi državni sekretar u skladu sa američkim zakonom o imigraciji i državljanstvu, dopunjenim zakonom o antiterorističkoj borbi i smrtnoj kazni iz 1996. godine, označio je kao strane terorističke organizacije:

1. Abu Nidal Organization (ANO)

2. Abu Sayyaf Group

3. A1 - Agsa Martyrs Brigade

4. Armed Islamic Group (GIA)

5. Asbat al - Ansar

6. Aum Shinrikyo

7. Basque Fatherland and liberty (ETA)

8. Communist Party of the Philippines /New people's Armu (CPP/NPA)

9. Gama'a al - islamiyya (Islamic Group)

10. HAMAS (Islamic Risistance Movement)

11. Harakat ul - Mujahidin (HUM)

12. Hizballah (Party of God)

13. Islamic Movement of Uzbekistan (IMU)

14. Jaish - e - Mohammed (JEM) (Army of Mohammed)

15. Jemaah Islamiya organization (JI)

16. al - Jihad (Egyptian, Islamic Jihad)

17. Kahane Chai (Kach)

18. Kurdistan Workers' Party (PKK) a. k.a.

19. Kurdistan Freedom and Democracy Congress (KADEK)

20. Lashkar - e Tayyiba (LT) (Army of the Righteous)

21. Lashkar i Jhangvi

22. Liberation Tigers of Tamil Eelam (LTTE)

23. Mujahedin - e Khalg Organization (MEK)

24. National Liberation Army (ELN)

25. Palestinian Islamic Jihad (PIJ)

26. Palestine Liberation Front (PLF)

27. Popular Front for the liberation of Palestine (PFLP)

28. PFLP - General Command (PFLP - GC)

29. al - Qaida

30. Real IRA

31. Revolutionary Armed Forces of Colombia (FARC)

32. Revolutionory Nuclei (formerly ELA)

33. Revolutionary Organization 17 November

34. Revolutionary People's Liberation Army / Front (DHKP/C)

35. Salafist Group for call and Combat (GSPC)

36. Shining Path (Sendero Luminoso, SL)

37. United Self - Defense Forces of Colombia (AUC) 
Interesantno je upoznati se sa definicijom terorizma koju nudi američki federalni istražni biro - FBI, u kojoj se kaže; „erorizam je nezakonito korišćenje sile ili nasilja protiv lica $i$ imovine da bi se zastrašila ili prinudila na ustupke vlada, civilno stanovništvo ili bilo koji njihov segment radi postizanja političkih ili socijalnih ciljeva“. Međutim u SAD-u u samo šesnaest saveznih država terorizam je označen kao krivično delo, dok se pomaganje terorizma na celoj teritoriji SAD-a ne smatra prikupljanje novčanih sredstava ili drugih materijalnih dobara i sredstava za terorističke organizacije ako se tim prikupljenim sredstvima i novcem ne kupuje i ne transportuje oružje sa teritorije SAD-a i ako teroristička organizacija za čiji račun se prikupljaju sredstva nije na spisku terorističkih organizacija koji ustanovljava američka administracija.

Jedan od očitih praznina ovako selektivnog spiska je veoma javno lobiranje u američkom senatu od strane Albanske dijaspore, postojanje organizacije koja prikuplja pomoć za teroriste na Kosovu i Metohiji, okupljanje dobrovoljaca za dopunu redova, tzv. OVK-a, pa i ponude raznih specijalizovanih propagandnih agencija za psihološko - propagandnu delatnost u korist seceonista sa Kosova i Metohije što po osnovu ovakve zakonske regulative mogu potpuno legalno da se odvijaju.

Zbog toga mada postoji naizgled jasan stav SAD-a po pitanju terorizma, zvaničnici pojedinih zemalja pa čak i međunarodne organizacije i institucije i dalje imaju teškoće u određivanju karaktera i delovanja „Militantnih grupa“, pa otuda i pojava dvostrukih standarda u određivanju šta je a šta nije terorizam. U suštini sve ono što ne pogađa direktno SAD i Zapad ne smatra se terorizmom, već predstavlja neki oblik borbe za "demokratiju i poštovanje ljudskih prava" - kategorije na koje je Zapad jako ponosan i koje i te kako eksploatiše kada su u pitanju drugi narodi i države.

Ono što suštinski odlikuje terorizam jeste slepo neselektivno nasilje u kome se ne prave nikakve razlike. Civili se smatraju legitimnim metama u terorističkim kampanjama usmerenim na postizanje ciljeva, koji bi se inače mogli smatrati vrednim i održivim. Terorista opravdava terorizam kao jedino oružje koje stoji na raspolaganju slabima.

Bez obzira na to što su razni teroristički napadi izvršavali na raznim geografskim prostorima u neodređenim vremenskim razmacima to uopšte nije smetalo da među teroriste budu zastupljene sve ideologije i religije, sve društvene klase i slojevi što je opet bilo u zavisnosti od prirode samih terorističkih akata i zastupljenosti određenih političkih interesa i ciljeva.

Postoji dosta oblika terorizma a svaki je različit po svojim političkim ciljevima, sredstvima i mrežama kojima raspolaže. Neke terorističke organizacije su geografski određene dok druge imaju univerzalistički karakter zbog sredstava koje koriste i mesijanske uloge koje su sebi dodelile.

Brojne studije koje su proteklih godina bile posvećene terorizmu dale su opšti prikaz delovanja različitih grupa.

Eksperti tvrde da se sve manje primenjuju stari oblici terorizma. Naime, sve je manje tradicionalnih, čvrsto organizovanih i iz jednog centra rukovođenih terorističkih organizacija i mreža a sve više „domaćih" etnički i verski inspirisanih terorista kojima je publicitet dovoljna nadoknada za sve rizike koje preduzimaju i izvrše.

Istraživajući neke nove terorističke akte grupa francuskih analitičara je zaključila da je većina terorističkih aktivnosti tzv. gradske gerile izvedena u blizini sedišta velikih informativnih agencija u vreme pripreme udarnih informativnih emisija na radiju ili televiziji ili u vreme održavanja neke medijske zanimljive aktivnosti. 
Osnovni razlog za to je zamisao za medijsku prezentaciju terorističkog dela. Drugim rečima „Oduzmite teroristima mogućnost predstavljanja njihovog dela preko sredstava javnog informisanja, smanjili ste efekte terorističkih akata na javno mnjenje za bar pedeset posto".

Za izvršenje raznih oblika terorističkih napada teroristi koriste raznovrsna sredstva. Raznovrsnošću ovih sredstava svakako doprinosi nagli razvoj nauke i tehnologije, što ovoj aktivnosti daje veći stepen opšte opasnosti i bezobzirnosti.

Na kraju o raznovrsnosti i opsega definicija terorizma dovoljno govori podatak Šmita i Jaugmana koji su u periodu od 1963. godine do 1981. godine izdvojili čak 109 definicija terorizma ${ }^{8}$.

Danas ih u svetskoj teoriji ima preko 300 i sve to unosi dodatnu konfuziju i otežava suprotstavljanju terorizma iz prostog razloga jer se teško suprotstaviti nečemu što je u svojoj definisanosti nedovoljno jasno i neodređeno, a posebno od svih relevantnih međunarodnih faktora selektivno i nejedinstveno prihvaćeno.

\section{Zaključak}

Kuda ide ovaj svet? Da li se već ostvaruje religiozno predskazanje o nestanku ljudske civilizacije i uopšte živog sveta početkom trećeg milenijuma? Zloupotreba nauke je postala najmoćnije učestalom pojavom terorizma i naročito dostizanje njegovog vrhunca 11. septembra 2001. godine svetski poredak se suočio ne samo sa novim pretnjama po međunarodni mir i bezbednost već i sa globalnom opasnošću po ljudski rod i čovečanstvo u celini.

I pored svoje duge i promenljive istorije terorizam je u prvim godinama ovog veka prevazišao sve prethodno postavljene granice. Veliki i nepredvidivi talas međunarodnog terorizma se nesumnjivo širi po celoj zemaljskoj kugli ostavljajući za sobom kao posledicu pustoš, miris straha, užasa i smrti najviše nedužnih ljudi. Kraj ove spirale monstruoznosti nemoguće je predvideti.

Za razliku od terorizma u prethodnim godinama ljudske istorije koji je bio prostorno ograničen na jednu državu u eri takozvanog "novog“ - savremenog terorizma čitav svet je pretvoren u arenu terorističkih akcija.

Za sada je prosto nemoguće dati odgovor na pitanje - kako zaustaviti terorizam?

Po nekim analitičarima kao prvo i osnovno treba zatvoriti sve informacije o njemu. $\mathrm{Ne}$ smeju izaći u javnosti nikakve informacije o terorističkim akcijama jer teroristi takve akcije i vrše upravo da bi skrenuli pažnju na sebe. lako je ova teorija nesumnjivo realna i delimično prihvatljiva postavlja se pitanje da li smo sposobni da prećutimo Madrid, Goraždevac, Njujork, Moskvu, Beslan, London i sva druga mesta u kojima su ostvarene neke sulude verske, političke, socijalne i druge ideje i nekakvog suludog cilja svojim životima platili nedužni ljudi pa čak i deca.

Posebno smatram da se terorizam može eliminisati samo ukoliko se iskorene društveni, politički, ekonomski, verski i svi drugi uzroci koji su ga prouzrokovali i inicirali. Iz opravdane bojazni smatram da je ovaj zadatak pretežak pa možda i neostvarljiv za ovu civilizaciju u kojoj živimo.

\footnotetext{
${ }^{7}$ Žerar Šalian, francuski analitičar i dobar poznavalac borbe protiv terorizma.

8 „Savremeni terorizam“ Radoslav Gacinović, str. 24, Grafomark, Beograd 1998. godine.
} 
Samo bi stvaranje jedinstvenog fronta i hvatanje u koštac sa ovom bolešću modernog čovečanstva sigurno dalo velike rezultate, u suprotnosti bićemo očevici velikih pretnji, straha i stradanja sa nesagledivim posledicama.

Konačno se mora shvatiti da nema dobrog i opravdanog terorizma kao ni dobrog $i$ ispravnog teroriste. Takođe nema ni jednog ispravnog cilja ni ideologije čije ostvarenje vodi preko stotinu i stotinu nedužnih i nevinih ljudskih života.

Porast verskog terorizma i njegova učestala pojava poslednjih godina kao pogonske snage koja stoji iza sve veće smrtnosti u međunarodnom terorizmu razbija neke pretpostavke o teroristima i nasilju koji oni čine. On takođe pokreće ozbiljna pitanja o valjanosti konvencijalnih saznanja o terorizmu, naročito s' obzirom na mogućnost upotrebe oružja za masovno uništenje sa strane terorista. U prošlosti takva mogućnost nije nikada razmatrana. Smatralo se da teroristi više žele da bude više ljudi koji će posmatrati njihova nedela nego onih koji će nastradati. Zbog svega ovoga mnogi su verovali da teroristi nisu previše zainteresovani za ubijanje, posebno ne selektivnog tipa. Dok neki od ovih argumenata možda još uvek važe za većinu neverskih terorističkih organizacija, incidenti poput onoga sa nervnim gasom u Tokijskom metrou i posebno napad na svetski trgovinski centar, koje su izazvali verski teroristi, čine ove argumente u potpunosti neodrživim. Jedan od aksioma terorizma jeste da on mora da stvara publicitet i da skreće pažnju kod onih prema kojima je uperen i prema javnom mnjenju na svoju borbu. Zato se teroristički akti lako pretvaraju u velike medijske događaje. Apsolutno ih je teško medijski sakriti te im ne dati publicitet iz razloga što je krajnji bilans pored velike materijalne štete veliki broj nedužnih žrtava.

Antikolonijalni terorizam je ključan u shvatanju evolucije, nastanka i razvoja savremenog modernog terorizma. Ovakve terorističke operacije bile su prve koje su dale pouku koliku važnost ima publicitet. Sposobnost antikolonijalnih terorističkih grupa da steknu simpatije i podršku van granica stvarnog poprišta predstavljala je pravu lekciju drugim narodima koji su sada u terorizmu videli efikasno sredstvo i način za pretvaranje do tada lokalnih sukoba u međunarodna pitanja. Na taj način su krajem šezdesetih udareni temelji za transformaciju terorizma iz prvenstveno lokalne pojave u bezbednosni problem globalnih razmera.

Ono što bi svetski poredak i čitavo čovečanstvo trebalo da zabrine je činjenica da postoje države koje otvoreno ili prikriveno podržavaju terorizam naočigled svih međunarodnih institucija koje su po tom pitanju veoma malo učinile da tu pojavu suzbiju ili je u potpunosti iskorene. Američki Stejt Department je 1996. godine označio devet zemalja kao sponzore terorizma: Avganistan, Albanija, Kuba, Iran, Irak, Libija, Severna Koreja, Sudan i Sirija. Protiv nekih od ovih zemalja SAD je pokretao niz kaznenih mera, ali ni ekonomske sankcije ni vojne intervencije se nisu pokazale naročito uspešnim u donošenju pozitivnih promena u politici ovih zemalja u vezi s' terorizmom.

Da li će se zatvaranjem očiju od strane međunarodne zajednice i dela globalnih svetskih kolos država nad aktima čečenskih terorista, terorista (UCK-OVK) i (ANA) i pravdanjem da je to borba za ljudska prava i sloboda građana globalno rešiti problem terorizma?

Da li su samo teroristički akti u pojedinim dominantnim državama opasni po čovečanstvo dok sve što se dešava u tuđem dvorištu ne predstavlja problem za širu svetsku zajednicu?

Dok se ovom problemu bude ovako pristupalo terorizam će uvek imati pogodno tle za svoj nesmetan razvoj i ekspanzionistički će rušiti sve pred sobom. 
Posebno bih istakao i konstatovao na kraju ovog dela: „Da je krajnji momenat za sve relevantne faktore u svetskom poretku da većinskim putem donesu konsenzus i definišu terorizam jedinstvenim pristupom, utvrde sve njegove oblike, sredstva, metode i dalekosežne posledice, stanu u jedinstven front i izvedu sveukupnu i jedinstvenu međunarodnu mobilazaciju antiterorističkih snaga"!

\section{Literatura}

[1] Dragan Simeunović, Teorija politike - rider, Nauka i društvo, Beograd 2002.

[2] Dragan Simeunović, Političko nasilje, NIRO, „Radnička štampa“ , Beograd 1989.

[3] Dragan Simeunović, Savremeni terorizam, Beograd 1992.

[4] Milan Petković, Teroristi, Kalekom, Beograd 1998.

[5] Stojan Jović, Specijalne snage, Montenegro, Harvest, Podgorica 1994.

[6] NIN, Terorizam, specijalni dodatak, 30.09.2004.

[7] Politička enciklopedija, Savremena administracija, Beograd 1975.

[8] Vojin Dimitrijević, Terorizam, Radnička štampa, Beograd 1982.

[9] Radovan Jović i Andreja Savić, Bioterorizam, institut za političke studije, Beograd 2004.

[10] Radoslav Gaćinović, Savremeni terorizam, Grafomark, Beograd 1998.

[11] Branko Cvjetković, Terorizam - sredstva i posledice, Laus, Split 2002.

[12] http: www google.co.yu IRA

[13] http: www google.co.yu ETA

[14] http: www google.co.yu TERORIZAM

[15] http: www google.co.yu AL - KAIDA 